\title{
Sources of stakeholder salience in the responsible investment movement: why do investors sign the Principles for Responsible Investment?
}

Article

Accepted Version

Majoch, A. A. A., Hoepner, A. G. F. and Hebb, T. (2017) Sources of stakeholder salience in the responsible investment movement: why do investors sign the Principles for Responsible Investment? Journal of Business Ethics, 140 (4). pp. 723-741. ISSN 1573-0697 doi:

https://doi.org/10.1007/s10551-016-3057-2 Available at https://centaur.reading.ac.uk/58168/

It is advisable to refer to the publisher's version if you intend to cite from the work. See Guidance on citing.

To link to this article DOI: http://dx.doi.org/10.1007/s10551-016-3057-2

Publisher: Springer

All outputs in CentAUR are protected by Intellectual Property Rights law, including copyright law. Copyright and IPR is retained by the creators or other copyright holders. Terms and conditions for use of this material are defined in the End User Agreement. 


\section{www.reading.ac.uk/centaur}

\section{CentAUR}

Central Archive at the University of Reading

Reading's research outputs online 


\title{
Sources of Stakeholder Salience in the Responsible Investment Movement: Why Do Investors Sign the Principles for Responsible Investment?
}

Arleta A. A. Majoch, ICMA Centre; Andreas G.F. Hoepner, ICMA Centre, and Tessa Hebb, Carleton University.

\begin{abstract}
Since its inception in 2006, the United Nations backed Principles for Responsible Investment (PRI) have grown to over 1,300 signatories representing over $\$ 45$ trillion. This growth is not slowing down. In this paper we argue that there is a set of attributes that make the PRI salient as a stakeholder and its claim to sign the six principles for responsible investment important to institutional investors. We use Mitchell et al.'s (1997) theoretical framework of stakeholder salience, as extended by Gifford (2010). We use as evidence confidential data from the annual survey of signatories carried out by the PRI in a five year period between 2007 and 2011. The findings highlight pragmatic and organizational legitimacy, normative and utilitarian power, and management values as the attributes that contribute most to the salience of the PRI as a stakeholder.
\end{abstract}

Keywords

Stakeholder salience theory, Principles for Responsible Investment, PRI, UNPRI, responsible investment, socially responsible investment, stakeholder theory

JEL Classifications

A01, G00, G1, G02

Acknowledgements

$(\ldots)$

Contacts

Arleta A. A. Majoch a.majoch@icmacentre.ac.uk 


\section{Introduction}

As recurring financial crises and financial market instability are prompting a reconsideration of how we invest (Woods and Urwin, 2010), there is increased interest from academics and practitioners in responsible investment strategies. Socially responsible investment (SRI) includes environmental, social and governance (ESG) factors in investment decision making. If responsible investment is part of the answer to the troubles of the financial system, it is important to know what causes investors to take this strategy on board. Institutional investors as a group of financial actors with distinct motivations (Jansson and Biel, 2011) and barriers (Guyatt, 2006) to adopting ESG are worthy of scrutiny. They control the majority of total shareholdings $84 \%$ in the UK (Mallin, 2007) - and in most countries account for the overwhelming majority of SRI assets (Jansson and Biel, 2011). A wide adoption of ESG by institutional investors would mean real momentum behind the ESG movement (Sandberg, 2011).

The United Nations-backed Principles for Responsible Investment (PRI) is a global organization that advances responsible investment with over 1,300 signatories representing over $\$ 45$ trillion (as of Dec. 2014). Because of its size, prominence, and first-mover status, the PRI is likely the most important global responsible investment initiative in existence today (Sandberg, 2009; Woods \& Urwin, 2010). The combined impact of the PRI's activity has firmly put responsible investment on the map (Sievanen et al., 2013). As Sophia Grene wrote in the Financial Times in 2009: "That sustainability is no longer a niche concept, sitting in the corner with the church groups and green evangelists, can be demonstrated by figures from the UN Principles for Responsible Investment".

Why have over 1,300 institutional investors decided over the last 9 years to sign the PRI? Why dedicate resources that would otherwise be used to satisfy other stakeholders' claims, to the annual reporting, signatory fees and implementing the six PRI principles? To analyze this question we use the framework of institutional theory which unpacks the way institutions respond to external pressures beyond their internal mandate (DiMaggio and Powell, 1983; Dorado, 2005; Greenwood and Hinings, 1996; Greenwood et al., 2011; Lounsbury, 2007). We will explore the stakeholder relationship between the PRI and investors to find out what makes the PRI's claim salient to these investors. For that purpose, we use a set of attributes first identified by Mitchell et al. (1997) and then expanded by Gifford (2010) as to what makes stakeholders and their claims salient to organizations. 
While there has been much speculation, there are currently no other empirical studies as to why investors have chosen to sign these principles. It is the motivation of this paper to shed some light on that question, using an important confidential dataset obtained directly from the PRI drawn from annual surveys over a five year period (2007-2011) of their signatories. This confidential dataset has been provided to us exclusively for the purpose of this study.

Insert figure 1

To tackle the question why institutional investors sign the PRI, we have to think of the investment firm as an organization that has stakeholders with competing claims. This is a new way to look at investors, as the academic literature to date, usually describes them as stakeholder's of the firm (Brower and Mahajan, 2013; Verbeke and Tung, 2013). The PRI with its objective of pushing SRI into the mainstream via its signatory body is affected by the institutional investor's adoption or rejection of the principles, making the PRI a stakeholder to investors according to Freeman's (1984) definition of stakeholder. Observing the principles and the commitment to them is the claim that the PRI makes of all institutional investors. Therefore, signing the PRI for the purpose of this paper counts as prioritizing a stakeholder's claim based on its salience. Competing stakeholder claims would be e.g. the clients' or beneficiaries' lack of expressed interest in RI, competing reporting frameworks that would claim the resources otherwise dedicated to the PRI annual reporting and implementation of the principles, or the investment team's entrenchment in their existing mainstream investment approach.

We code five years of signatories' responses to the question of why they signed the principles and what they perceive to be the benefits of signing, in search of evidence of the attributes of power, legitimacy, urgency, management values, coalition building and relative economic size (Gifford, 2010; Mitchell et al., 1997) contributing to the salience of the PRI's claim in the eyes of investors.

The paper will first introduce the conceptual background, exploring existing literature on institutional theory and stakeholder relationships in the context of responsible investment. Next, the theoretical framework and its application will be detailed. In the following parts, we describe the dataset and methodology. The final parts of the paper present and discuss the findings. The paper closes with research limitations and conclusions. 


\section{Conceptual background}

The PRI is a global investor association founded in 2005 with the backing of the United Nations and the objective of promoting the six Principles for Responsible Investment and helping institutional investors who sign to implement them. Institutional investors are defined as organizations that manage and invest on behalf of clients and beneficiaries. This includes pension funds, banks, asset managers, insurers among other types of organizations (Sandberg, 2011). Devised by the investment community itself, the principles form a framework for incorporating environmental, social and governance issues into investment decision making. They are based on the conviction that ESG factors have an impact on the performance of investments.

Insert figure 2

(6 principles)

The PRI's voluntary and aspirational nature means that there is a large heterogeneity of ESG advancement among its one thousand-odd signatories. Therefore being a signatory to the principles is not necessarily synonymous with being a responsible investor. However, the mere act of signing the principles remains worthy of scrutiny, as, in the words of PRI founder James Gifford: "The important thing is to get people in the tent, for whatever reason. Then once they are in, you can start to inspire change". (Gifford, 2014, pers. comm., 15 June) This mechanism of gradual decrease with time in the gap between declared policy and practice is documented in academic literature on decoupling (Boxenbaum \& Jonsson, 2008; Bromley and Powell, 2012; Edelman, 1992; Hallett, 2010; Sauder \& Espeland, 2009, Scott, 2008; Tilcsik, 2010), most relevantly in Haack et al.'s (2012) study on the adoption of the Equator Principles that finds decoupling to be a transitory phenomenon. The PRI is not an isolated phenomenon in the contemporary institutional landscape. In the area of responsible investment regional Social Investment Forums (SIFs) and the United Nations Environmental Program Finance Initiative (UNEP FI) are also important organizations.

Institutional theory has made many valid attempts to systematize the way we look at industry initiatives of similar nature (Dumas and Louche, 2011; Gond et al., 2011). Especially the literature on private regulation and multi-stakeholder initiatives (MSIs) has contributed significantly to this effort (Bartley 2007; Hardenbrook, 2007; Mena and Palazzo, 2012). It is worth highlighting that the PRI differs from the organizations studied by the MSI literature in that it does not have regulatory characteristics per se as the six Principles in and of themselves are not overly prescriptive. 
However, despite their differences in perspective, institutional theory and stakeholder theory overlap significantly and share a common interest: explaining how organizations ensure survival and growth (Chen and Roberts, 2010). External pressures explored in institutional theory and questions of power, legitimacy and other sources of influence (Markowitz et al., 2008) are also incorporated into the study of stakeholder relationships. In contrast to institutional theory, stakeholder theory with its focus on the firm, emerged in opposition to the shareholder view of the firm, according to which the only relevant stakeholder of the firm is the shareholder. Stakeholder theory argues that the tension or alignment between the interests of managers and shareholders is not the only relationship that is relevant to a corporation (Freeman, 1984; Donaldson \& Preston, 1995). From there, stakeholder theory developed and established itself throughout the 1990s with contributions from Goodpaster (1991), Clarkson (1994, 1995), Donaldson and Preston (1995), Rowley (1997) and Frooman (1999) being among the most prominent ones. Because of its firm-level unit of analysis, it has been used in studies in the field of responsible investment to examine stakeholder relationships between actors, for instance NGOs and the investment community (Guay et al., 2004).

Kaler (2006) names one of the functions of stakeholder theory in the field of business ethics as being a tool for understanding CSR. One of the characteristics that make it suitable for that application is that it is managerial (Donaldson and Preston, 1995) in the sense that it is useful in directing managers towards the serving of particular interests. For as long as the interests served by organizations were primarily the financial interests of shareholders and owners explaining that status quo did not present a challenge. However, in an increasingly mobilized society (Power, 1994; Strathern, 2000) where NGOs, employees, suppliers, governments are more active in presenting their claims of organizations, how do managers decide which of those claims are worthwhile in terms of dedicating limited resources of time, labor and capital to them? While in the past investors were seen as a stakeholder, this paper argues that investors themselves are increasingly the object of other stakeholder claims. How do they choose between these competing demands? Here the notion of stakeholder salience theory becomes useful. And it is a variation of that same question that this paper addresses: why do institutional investors choose to satisfy the claim of signing the PRI among many other stakeholder claims addressed at them?

In this paper, we choose to apply Mitchell et al.'s (1997) stakeholder salience model, following Gifford (2010), as one of the most influential frameworks in the literature (Mainardes and Raposo, 2012) ${ }^{1}$. There are important advantages to Mitchell et al.'s model that explain its 
widespread adoption. It is political, acknowledging the organization's position at the intersection of conflicting and unequal interests. It is practical and easily operationalized, offering versatile and relevant categories applicable to varied stakeholder relationships (Tashman and Raelin 2013). It is also dynamic, recognizing that stakeholder relationships are transient and although not exploring that aspect of the relationships extensively, it leaves space for its inclusion (Friedman and Miles, 2002; Myllykangas et al. 2010; Mainardes and Rapso, 2014).

Mitchell et al.'s model has been applied extensively to examine an organization's relationship with different stakeholders (Harvey and Schaefer, 2001; Parent and Deephouse, 2007; Mainardes and Raposo, 2012; Brower and Mahajan, 2013; Chang et al., 2014) but it has rarely been applied empirically to focus in detail on a particular stakeholder relationship, which this paper undertakes.

This framework has also been further developed by Gifford (2010) specifically in the context of responsible investment, making the extended version a highly adequate tool for addressing the particular stakeholder relationship in question. Mitchell's et al. stakeholder salience model and Gifford's additions to it are described in more detail in the next section of the paper.

\section{Theoretical framework}

Mitchell et al.'s stakeholder salience model is a tool both for the identification and the prioritization of stakeholders and their claims (Neville et al., 2011). In this paper the underlying assumption is that the PRI is a stakeholder from the perspective of investors, with its mission of 'understanding the implications of sustainability for investors and supporting signatories to incorporate these issues into their investment decision making and ownership practices' (PRI website, 2014). The PRI's stakeholder claim that management prioritizes over others or not is that an investment institution should sign the principles.

As stated in the introduction, it is more common for the investor to be considered as a stakeholder from the perspective of the firm (Kaler, 2003). While this is the natural approach in questions relating to corporate strategy, when discussing investment, stakeholder relationships from the investor's perspective become relevant. From the investor's perspective it is the PRI that is a stakeholder (Freeman, 1984). Either its claim is salient to investors and they become a signatory or it is not and they do not sign, following Eesley and Lenox's (2006) action-based definition of salience. Taking this approach contributes to the work within stakeholder theory that has been undertaken to expand our views of stakeholders and stakeholder relationships (Crane and Ruebottom, 2011; Rowley, 1997). It also follows the lead of scholars who have 
applied stakeholder theory to different types of institutions, for instance Knox and Gruar (2007) who take the perspective of a non-profit organization and examine stakeholder relationships from its perspective A more recent example is a paper by Sobczak and Harvard (2014) discussing the influence of NGOs, government, members and other stakeholders on labor unions. The theoretical framework is applied to identify to what degree the PRI's stakeholder claim possesses the salience-producing attributes as predicted by Mitchell et al. These attributes are: power, legitimacy and urgency.

Mitchell and his co-authors adopt Etzioni's (1964) typology of power. Power concerns the coercive, utilitarian or normative means that a stakeholder has at their disposal to exert influence on management. Coercive power relates to the use of force, restraint or violence to achieve the actor's desired outcome despite resistance (Weber, 1947). Utilitarian power is based on material resources e.g. shareholders exercise utilitarian power by means of financial reward or punishment i.e. investment or divestment. Using normative power is linked to symbolic resources, such as media attention or reputation.

Legitimacy and urgency apply to how the claim itself is viewed by the management. Legitimacy is 'a generalized perception or assumption that the actions of an entity are desirable, proper, or appropriate within some socially constructed system of norms, values, beliefs, and definitions' (Mitchell et al, 1997). Mitchell et al. divide it into individual, organizational and societal legitimacy where the degree of legitimacy is tied to the perception of an individual, the whole organization, or society's expressed endorsement of the claim as legitimate.

Gifford (2010) introduces another moderating factor, which is pragmatic legitimacy. It refers to the business case perspective on the stakeholder's claim. It is determined by the strength of the arguments presented by the stakeholder, and the amount of new information they present to the management.

The final factor presented by Mitchell et al. is urgency. It refers to the degree to which the claim is perceived by management as calling for immediate attention. According to Agle, Mitchell and Sonnefeld (1999) urgency can be a crucial factor in achieving maximum salience. Urgency has two sources: time-sensitivity and criticality, time-sensitivity coming from time pressure and criticality the importance attached to the claim by the stakeholder. For example in Gifford (2010) stakeholders signal criticality by being persistent, assertive and by dedicating significant resources to advancing their claim.

Gifford (2010) expands Mitchell's et al. model, based on its application to a shareholdercompany relationship in an engagement context. Besides the additions already mentioned, he 
expands the framework with four moderating factors of pragmatic legitimacy, management values, the relative economic size of the stakeholder and coalition building. Gifford also adds a temporal dimension to the relative importance of these factors, in that different sources of salience are added to the equation during the interaction with the stakeholder, rendering the model even less static. This is also the way institutional theory has evolved from its early static view of institutions to more dynamic models that take into account the existence of competing logics (Meyer and Hollerer, 2014).

Pragmatic legitimacy is the perceived legitimacy of the stakeholder claim as well as the value and relevance of the new information that the claim brings to the attention of managers that they would not otherwise have considered.

Management values are defined as the degree of overlap between the values expressed through the stakeholder claim and the values of managers. It can moderate salience independently of the attributes proposed by Mitchell et al (1997).

The size of the stakeholder relative to the company contributes to salience through the increased power and legitimacy that stem from it. For example a larger shareholder is likely to hold a more significant stake in a smaller company, and have more access to governance power as a result. Likewise, they are likely to be a more legitimate and important actor on the market.

The final moderating factor - coalition-building - refers to the pooling of resources by stakeholders. A stakeholder coalition has the combined size, resources, legitimacy etc. of its participants (e.g. coalitions of shareholders, policy makers or NGOs). It is therefore a moderating factor of power, legitimacy and urgency.

\section{Applied framework}

The application of stakeholder salience theory to the research question 'Why do investors sign the PRI?' is complicated by the fact that for the purpose of this research, there is no single stakeholder whose claim's salience has specific attributes from the Mitchell and Gifford frameworks. Therefore, the analysis focuses on the salience of the claim rather than a particular stakeholder. The claim to sign the PRI presented to the investor can, and is advanced by the PRI itself, but in many cases it is also advanced by other stakeholders e.g. the trustees, an NGO, a senior manager, and it is in that context that it possesses some of the attributes that contribute to its salience. Freeman (1984) specified that perceived salience can result from the attributes of both a claim and a stakeholder group, as Eesley and Lenox (2006) confirm empirically in a study 
of stakeholder action on environmental issues. In the case discussed in this paper therefore the subject is the claim to sign the PRI but its salience may be attached to different stakeholders. Eesley and Lennox (2006) test the legitimacy and urgency attributes as applied to stakeholder claims in a data driven paper and obtain positive results. However, academic literature has generally focused on the salience of stakeholders rather than their claims. One of the contributions of this paper is to further explore the perceived salience of a stakeholder claim through empirical research.

Below we address each attribute from the Mitchell et al.'s (1997) and Gifford's (2010) framework and explain how it is applicable to the PRI-investor relationship. Each of these attributes is a potential source of salience of the claim to sign the PRI and in coding our dataset we look for evidence that backs this intuition.

As a voluntary and aspirational framework the PRI itself does not use the means of threat or coercion to influence an investor's decision to sign. Coercive power as a means of increasing the salience of the claim to sign the PRI would have to come from other sources such as regulatory bodies or trustees. A utilitarian, financial incentive is most likely to come from an investor's clients. The desire to attract new clients or to satisfy the demand from existing ones by signing the PRI would be examples of utilitarian power as a source of salience. The reputational benefits and the signaling of an ESG capability involved in becoming a PRI signatory are examples of normative power, as non-material, symbolic incentives to sign the PRI.

Urgency, as the degree to which a stakeholder's claim calls for immediate attention (timesensitivity), has its source in the increasing visibility of the PRI in the investment space and the pressure on investors to join the growing trend of responsible investment. The critical aspect can be found in the persistence of stakeholders asking investors to sign the PRI, and the amount of resources they dedicate to advancing their claim. Legitimacy in an investor-PRI interaction can stem from the legitimacy of the PRI as an organization (organizational legitimacy), of an individual (individual legitimacy) or from the perceived endorsement of the principles by society (societal legitimacy).

Gifford adds to the above the relative economic size of the stakeholder, which in this context becomes the size of the PRI and the growing weight of the AUM of the existing signatories; coalition building, i.e. stakeholders building coalitions to advance the claim of signing the PRI more effectively, for example the PRI securing the endorsement of the UN; management values which in the case of some investors may already be aligned with those represented by the 
Principles before signing; and pragmatic legitimacy in the form of a perceived business case behind the stakeholder claim, in this case the materiality of ESG issues in investment.

The temporal dimension of the model highlighted by Gifford is observed both in the importance of different attributes in each year of the sample and in the importance of different attributes over time to signatories who joined in each of the sample years. But empirical evidence is needed to deepen our understanding.

\section{Data and method}

The data for this study is sourced from a confidential dataset of annual questionnaires from 2007 to 2011 on the implementation of the PRI principles. This paper presents an analysis of responses from asset owners, asset managers and insurers. In the first few years of this period (2007 to 2010 ) the questionnaire was obligatory ${ }^{2}$. All responses from signatories who signed beginning in 2011 are voluntary.

The question coded for the purpose of this paper was 'Why did your organization join the PRI?' or 'Please describe the benefits you have enjoyed as a result of signing the PRI'. This question was optional and open ended. The table below gives some information on the question throughout the survey years and the makeup of the respondents.

\section{Insert table 1 here}

The question only corresponds directly to the research question in the years 2008 and 2009. The questions from years 2009-2011 are only related, and they approach the decision to sign the principles from a backward looking perspective, evaluating the positive results of the decision.

The number of responses to the relevant question remains at around or slightly below $90 \%$ of the total responses to obligatory questions and at around $60 \%$ of the total signatory number throughout the sample years. The geographical distribution of the sample is still overweight in developed regions, with very similar numbers in the general signatory body.

The proportion of asset managers vs. asset owners among the respondents gradually shifted over the years, in the sample analyzed as well as the rest of the signatory body. Among asset owners, $60 \%$ of assets were managed internally in 2011. Around half of asset owners are non-corporate

\footnotetext{
2 Signatories for whom the survey is obligatory have to respond to the survey each year. This means that depending on the organization, the same answers will be coded repeatedly over several years, or the organization will modify them year by year.
} 
pension funds, followed by the second largest group of corporate pension funds accounting for $25 \%$ of respondents in 2011. Among asset managers mainstream investment managers are responsible for $77 \%$ of the responses. They are followed by dedicated SRI Managers $-12 \%$, and themed fund managers - 9\%.

Listed equity and fixed income are the two dominant asset classes accounting for $36 \%$ and $49 \%$ of respondents' assets in 2011 respectively. The third largest category (13\%) is cash, commodities and other assets.

The analytic method used in this paper is content analysis. It is defined as a research technique used to systematically make inferences about the intentions, attitudes, and values of individuals by identifying specified characteristics in textual messages that are assumed to be objective for the purpose of the study (Morris, 1994). It allows for the systematic, numeric analysis of a large amount of text in a manner customized to the research that is being conducted.

Content analysis has featured regularly in management literature (Bergh, 1993; Butterfield, 1996; Buttner, 2001; Davy et al., 1992; Molloy et al., 2011), accounting (Beck et al., 2010; Fischer, 2010), marketing (Hite et al., 1998; Burnett et al., 1991; Rust and Cooil, 1994) and business ethics where it has been often applied to analyze large volumes of company produced publications relating to their ESG policies and activities (Holder-Webb et al., 2009; Jose and Lee, 2007; Lefebvre and Singh, 1992; Sheth and Babiak, 2010; Stray, 2008). It is also the dominant research method for collecting empirical evidence in the field of social environmental accounting (Parker, 2005). See Appendix 3 for a more detailed analysis of manual content coding.

Two reasons we chose manual coding over automated coding are specifically related to this PRI dataset. Firstly, the data was collected from organizations from over 30 countries. The differences in wording between even a handful of countries can be hard to manage in computerized coding, so we decided it would not be effective in a study with such broad geographical scope to correctly identify the entire variety of phrases for automated coding.

And secondly, responsible investment is an emergent field and does not have an established vocabulary (Sandberg et al., 2009), which makes discrepancies even more likely to obscure results when using automated coding. Based on this, the authors agreed that to obtain the most accurate results, we should use manual coding where the categories answers fall into are decided on a case by case basis. As observed by George and Louise Spindler (1997), 'only the human observer can be alert to divergences and subtleties that may prove to be more important than the data produced by any predetermined categories of observation or any instrument' (p.66-67). 
To ensure a high degree of reliability of the coding, it has been reviewed and discussed by James Gifford, founder and executive director of PRI until 2013, and author of extended theoretical framework used in this paper, as well as PRI staff members.

We use magnitude coding for each observation, following Wolfe, Gephart and Johnson's (1993) finding that counting each occurrence of an item in content analysis equally is a simplification and may produce misleading results. Units of text are coded on a scale: 0 - no support 1 - weak support 2 - moderate support 3 - strong support and 4 - very strong support. However, only units coded 2-4 contribute towards the results presented in the analysis section of this paper to exclude instances where the coding might depend more on the coder's interpretation of the text than its explicit message. The coding method applied is also simultaneous, meaning that each unit of analysis can be coded as supporting multiple attributes in the theoretical framework (Saldana, 2009). Following Gray et al.'s (1995) recommendation, the unit of analysis used is predominantly sentences, however in cases where responses are poorly structured or unnecessarily long, multiple sentences or responses as a whole are an alternative. Morris (1993) also observed that coding based on entire units of text results in higher agreement between coders and human and computer analyses, which provides justification to depart from sentences as units of analysis if they are not singularly significant enough.

\section{Data analysis and discussion}

We use descriptive statistics to demonstrate the importance of each factor and how it changed over time. We consider the absolute number of answers in support of an attribute in a given year and the number as a proportion of all the responses to the relevant question. We look at aggregate results from all signatories, as well as split into asset owners and investment managers, and by groups of signatories who signed in each sample year. The percentages in tables 2 to 4 below do not add up to 100 because they are a proportion of all survey answers submitted in the given year and the percentage not mentioned would not have been coded in support of any of the attributes.

Insert tables 2,3 and 4 here

\section{Power}

In considering the claim of signing the PRI, power as a source of salience is closely linked to the institutional investors' relationships with their other stakeholders, such as clients, regulators and society. Coercive power means that a stakeholder has the power to force an investor to sign the 
PRI, as for instance a legislator would. Normative power works through symbolic means such as the reputational consequences of rejecting or satisfying a stakeholder claim. Utilitarian power is exerted via material incentive, for example the awarding and withdrawing of pension fund mandates.

Coercive power as a source of salience of the claim to sign the PRI is not documented in the data. This was in line with the researchers' expectations based on the voluntary and aspirational nature of the PRI framework (Richardson, 2008; Scherer and Palazzo, 2010), and the lack of formal mechanisms of power active in the PRI-investor relationship such as legislation.

The strongest evidence emerged for normative power. 217 respondents in 2011 submitted answers that the researchers coded as support for the attribute of normative power being a source of salience in the decision to sign the PRI. This number grew from $3 \%$ in the first year of the sample, to $6 \%$ in 2008, 16\% in 2009 and 18\% in 2010 before reaching 47\%, almost half of the sample, in 2011. Normative power started out more prominently in the asset owner sample and continued to grow steadily, whereas in the investment manager sample it started out weaker but caught up with the asset owners by 2010. This translates to asset owners such as pension funds and insurers experiencing the reputational and other symbolic pressures and benefits earlier in the sample period, before they became a source of salience in the eyes of investment managers, possibly with the former driving the latter.

Mainstream investment managers and corporate pension funds were more influenced by normative power than their SRI and public counterparts. In $201140 \%$ of corporate pension funds and $21 \%$ of mainstream investment managers mentioned normative power in their responses, compared to $18 \%$ of public pension funds and $11 \%$ of SRI managers. This would suggest that the impact of the PRI stamp on mainstream investment manager and corporate pensions image and reputation is larger, perhaps because they start out with no responsible investment image while public pensions and SRI investors are more likely to have communicated an investment approach similar to the PRI principles even prior to signing.

The proportion of responses referring to utilitarian power display a similar growth, although slightly smaller, starting at 1\% in 2007 and slowly growing to 9\% in 2009, then eventually reaching $32 \%$ in 2011. Utilitarian power found more support among asset manager signatories, likely due to the power relationship between asset owners and investment managers where an ESG capacity is becoming a consideration in hiring managers. A mainstream Australian investment manager says 'We have been queried and reviewed by asset consultants and clients on our ESG activities' (PRI survey responses, 2010). A mainstream UK fund explains: 'Becoming a PRI signatory 
has also enabled us to respond positively to asset owner's RFIs and RFPs (requests for information and requests for proposal respectively) that increasingly ask about status regarding the PRI' (PRI survey responses, 2010). Therefore investment managers signing the PRI are responding to the material incentive of gaining new clients or satisfying the clients they already work for.

Asset owners quote the support and interest of their members as incentives, e.g. 'Supports the interests/needs of our membership' as stated by a Canadian public pension fund (PRI survey responses, 2010). These answers offer evidence that asset owners are becoming more confident about the place of ESG considerations in investment practice within a traditional fiduciary framework.

For added perspective it is useful to look at the distinction between the proportion of mainstream vs. SRI investment manager responses and public vs. private pension fund responses coded in support of utilitarian power: $15 \%$ of all mainstream investment manager responses to the questions were coded in support of utilitarian power in 2011, compared to $11 \%$ of SRI managers. The proportion of mainstream investment manager responses remained higher throughout the sample, suggesting that this group is more financially driven than SRI managers.

A parallel pattern is clear among asset owners in 2011 where $20 \%$ of corporate fund responses were coded in support of utilitarian power, compared to $12 \%$ of public funds, again likely because of the more financially-driven character of corporate pensions compared to public pensions.

It is also interesting to see that the growth of support for the power attributes are not as sharp among signatories who signed the PRI in the first two years as it is among the later years. This indicates that these two groups are most driven by different attributes: the earlier signatories are less likely to have signed for reputational gains, or to attract new business, than their later counterparts who were perhaps looking for those benefits as the PRI accelerated the growth of ESG in the industry. This divide between the early and the later signatories is reinforced by the difference in their support for management values and pragmatic legitimacy and is consistent with Gifford's (2010) temporal aspect where different attributes have varying importance to the stakeholder relationship in time.

The dominant role of normative and utilitarian power as a factor contributing to ESG related behavior by organizations does not come as a surprise considering the degree to which it has been present in previous literature on the topic of CSR and SRI adoption. In terms of utilitarian power Mackey et al. (2007) propose a model where ethical activity is beneficial to the organization conditional on a favorable supply and demand balance. This angle of analysis is seconded by Barnett (2007), and corresponds to investors signing the PRI to meet client 
demand, more pronounced among asset managers, as their asset manager clients are more likely to clearly communicate ESG requirements.

This source of salience is also theorized in the form of relational organizational identity orientation in Brickson (2007). Brickson distinguishes between collectivistic, relational and individualistic organizations, each of which responds primarily to values-based, client-related and material incentives respectively. Investors signing the PRI in response to client expectations or in an effort to attract clients would be placed somewhere between relational and individualistic orientation, depending on how much it is utilitarian and normative power related to client relationship and reputation and how much purely business-case type pragmatic legitimacy that drives their behavior (Brickson, 2007).

Normative power being an important attribute raises questions regarding a possible decoupling of policy and practice among PRI signatories (Crilly et al., 2012; Weaver et al., 1999). In this context it would mean investors signing the PRI to satisfy stakeholders and for reputational or signaling benefits while limited effort is made within the organization to integrate the principles into investment practice, a legitimacy-seeking strategy described in detail by Long and Driscoll (2008). Based on our data we cannot conclude if that is the case but it is a possibility that could be explored by further research.

\section{Urgency}

We find no support in the data for urgency as a source of salience. Signatories make no explicit reference to the timing aspect of the claim to sign the PRI, or pressure resulting from the intensity of resources used by stakeholders in advancing it. This may be explained in part by urgency being part of the investor-client relationship where an organization considers joining the PRI for a long time and a conversation with a client who communicates that they are transitioning towards all-PRI-signatory managers delivers the final push (Gifford, 2013, pers. comm.). It is likely that such instances would be reported as utilitarian incentive without mention of the urgency component.

Other studies in the area of stakeholder salience have reached conflicting conclusions on urgency being a contributing factor (Hautbois, 2012; Parent and Deephouse, 2007; Neville et al., 2011; Weber and Marley, 2010) and in this paper we cannot establish its relevance based on the data despite considerable anecdotal evidence in its favor (Gifford, 2013, pers.comm.).

\section{Legitimacy}


Of the legitimacy attributes, individual legitimacy is not documented in the data, as signatories do not make reference to individuals having a role in advancing the claim to sign the PRI. Individual legitimacy was also amongst the less salient attributes in Gifford's (2010) study of stakeholder engagement but it has otherwise not been explored empirically in stakeholder theory literature. There is some discussion in the literature based on mainly qualitative evidence that individuals can play a catalyzing role in institutional transition in an ESG context (Lewis and Juravle, 2009; Waddock, 2010).

The presence of organizational legitimacy in the survey responses has grown steadily over the sample period. Signatories refer to the legitimacy of the PRI as an organization adding to the salience of the claim to sign, and also to the PRI conferring legitimacy on their own organization and their SRI efforts of joining a leading initiative in the responsible investment space (Long and Driscoll, 2008; Perez-Batres et al. 2012).

For instance, a mainstream European fund says signing the PRI 'grants credibility to its commitment to sustainability and corporate governance principles' (PRI survey responses, 2011). A Canadian public pension fund quotes to be 'benefiting from the credibility of the PRI in the investment community as well as with companies we engage with' (PRI survey responses, 2011).

Societal legitimacy defined as the perception of social support for a claim has had a small but constant presence in signatory responses. Investors see signing the PRI as a step towards aligning their goals with the goals of society, or being better attuned to society. It is difficult to hypothesize about why societal legitimacy was not an important factor to investors - other than investors feeling little pressure from the side of society as most ESG social pressure is focused on corporates. As observed by Baron (2009) who discusses societal pressures on organizations to engage is CSR, society is not explicit in manifesting its preferences, and may therefore be difficult to quote as a source of salience. Support for societal legitimacy was slightly more pronounced among public pension funds and SRI managers than mainstream investment managers and corporate pensions - at an around $5 \%$ and $1 \%$ mean respectively - again consistent with the generally more socially oriented character of the former (Blackburn 2006; Sethi, 2005; Sievanen et al., 2013).

\section{Extended theoretical framework}

Of the Gifford additions to the stakeholder salience model are relative economic size and coalition building, but these attributes were not supported significantly by the data in this study population. Relative economic size in the form that Gifford introduces it to the model is reminiscent of institutional isomorphism in institutional theory (DiMaggio and Powell, 1983) 
where the PRI as a growing trend in the industry would encourage larger and larger numbers of investors to sign. This may well be the case although it is not recognized by investors as a contributing factor to their decision to sign, or not reported as such. The relative size of assets is only reported as a significant factor in the context of coalition building opportunities for signatories amongst themselves via the Clearinghouse. That is also the context in which coalition building is mentioned overwhelmingly by signatories, and also in literature, for instance as collectivistic organizational identity orientation in Brickson (2007) or membership of industry associations as a moderating factor of social responsibility of organizations in Campbell (2007). Neither coalition building nor relative economic size as defined in Gifford's extended model play a role in adding salience to the claim of signing the PRI itself.

\section{Pragmatic legitimacy}

Pragmatic legitimacy in the sense of a business case or supplying management with new and relevant information is found in a growing number of responses over the sample period. At the end of the sample period almost 50\% of investment manager signatories referred to the PRI as supplying relevant ESG integration methods and information, up by 20 percentage points from 2007. The proportion of asset owners grew in absolute numbers over the years but remained at around $30 \%$ of responses proportionately. This is consistent with the fact that investment managers should be more responsive to the business case argument given that they are the most performance oriented and are in charge of investing the assets, whereas asset owners manage a minority of their assets internally.

Signatories see the value of the PRI in access to know-how, best practice, research and trends in the responsible investment. They see the PRI as a learning tool for their organizations in the transition towards an ESG integrated investor, via webinars, discussions with other investors, implementation support, collaborative engagements and the association's research outputs. For instance, a French asset manager says: 'The PRI provides an ambitious roadmap for continuous improvement with clear signposts and long term objectives. Our organization has managed, through its involvement in the past year, to move towards greater ESG integration more broadly (additional asset classes) and more deeply (from SRI to mainstream)' (PRI survey responses, 2011). A Brazilian investment manager describes the PRI as follows: 'We have found a framework that accommodated our pre-signing beliefs related to ESG issues and value creation, and helped us organize or re-shape our internal analysis processes around the principles' (PRI survey responses, 2011).

This finding is in line with much of the responsible investment literature that acknowledges the increasing realization among investors that SRI is a value-creating approach (Ctifo and Forget, 
2012; Louche, 2009) and that investors follow up their investment beliefs with actions (Woods and Urwin, 2010). It is also in line with Arjalies' (2010) social movement perspective on the development of SRI, where institutions seek to incorporate a new emerging logic into their existing institutional logic to create a new mainstream hybrid. The structure and know-how provided to its signatories by the PRI helps investors with this process, therefore pragmatic legitimacy contributes to the salience of PRI's claim.

\section{Management values}

The salience of management values were strongly supported in the first two years of the PRI surveys, but support dropped dramatically in the subsequent years. In the years 2007, a staggering $90 \%$ of asset owners and $60 \%$ of asset managers explain their decision to sign the PRI by stating that the values of the PRI reflect the values of their organization, therefore it is a natural step. In 2008 the asset owner number drops to 70\% while the asset manager number stays the same, but by 2009 evidence in both investors groups is only found in $10 \%$ of responses. This number does not grow in the rest of the sample period. The groups of signatories that signed after year 2008 do not report on management values at all. It is the first signatories from 2006 and 2007 that drive the support for this attribute.

A possible explanation of the great prominence of management values in the first years of PRI's existence and why it was followed by its relative unimportance in the subsequent years is that the first wave of signatories would have been those investors who were already ESG minded. They made up most of the signatory body in the years 2007-2008, but by 2009 other factors such as the legitimacy of the PRI, utilitarian incentives, or pragmatic legitimacy attracted large numbers of mainstream investors who placed less emphasis on the alignment of values in their thinking about the benefits of signing the PRI. This is consistent with the social movement perspective on the evolution of responsible investment from activist and socially driven to profitdriven (Markowitz et al. 2008). Other studies provide contrasting evidence, such as Jansson and Biel (2011) who find that institutional investors are not values-driven as opposed to individual investors (McLachlan and Gardner, 2004). It is however challenging to relate management values in the sense that they are manifested in the PRI-investor relationship to how they are understood elsewhere in the literature. The PRI principles convey little or arguably no moral values per se (Eccles, 2010), while values-driven organizations as defined by Baron (2009) or Brickson (2007) take into account higher order values that are morally determined.

Insert Figures 3 and 4 here 
In summary, the attributes from the Mitchell et al. framework most supported by the data are normative and utilitarian power, and organizational and to a lesser extent societal legitimacy. Of Gifford's additions to the framework, the attributes of management values and pragmatic legitimacy are the most prominent. The temporal aspect observed by Gifford is manifested clearly throughout the data in the variation over time in both the aggregate results and in results for investors grouped by signature year.

\section{Research limitations}

It is important to acknowledge the limitations of this research stemming both from the characteristics of the data and the method.

The data is self-reported, which has a potential distorting effect on the type of answers submitted. Moreover, the answers analyzed in the sample were not mandatory, meaning that the sample was likely to represent the more involved among the PRI signatory base, who dedicated resources above the minimum that is required to avoid delisting. If that is the case, the results might be only a biased reflection of the motivations of the entire signatory body. It is however reassuring that the geographical distribution and investor type break down is not too dissimilar between the signatories who answered the question annually and those who did not, which limits the risk of response bias. However a clear limitation is that geographical variation is not studied in this research, although it is acknowledged in the literature that responsible investment differs geographically (Sakuma and Louche, 2008; Sievanen et al., 2013; Sparkes, 2002). Detailed descriptive statistics comparing the two groups year on year can be found in Appendix 2.

The discretionary coding method is also a research limitation. It is hard to maintain consistency and lack of bias throughout the coding process for a human coder. The results are ultimately only one possible outcome of the analysis based on the interpretation of textual data by only one group of researchers.

The above research limitations are routinely found in survey based research (Agle et al., 1999; Harris, 2001; Hrashy, 2011; Shin, 2012; Valentine and Fleischman, 2008). They are an obstacle to this type of study being precise and exactly representative of reality. Therefore the numbers quoted in the paper should be treated as a rough estimate of general trends among a sample of PRI signatories as reported by themselves, and as analyzed by a small team of researchers and not necessarily an accurate quantitative illustration of investor motivations. 


\section{Conclusions}

In this paper we have argued that there is a set of attributes that make the PRI as a stakeholder and its claim to sign the six principles for responsible investment salient to institutional investors. The dataset provides evidence of the stakeholder relationship between investors and the PRI as defined by Freeman (1984) and according to Mitchell et al.'s (1997) stakeholder identification framework. The PRI has the legitimacy, power and management values attributes that contribute to stakeholder salience. Based on an examination of five years of predominantly confidential survey data from PRI signatories spanning the period from 2007 to 2011, we find that the attributes that contribute most to the salience of the PRI and its claim are organizational and pragmatic legitimacy, utilitarian and normative power, and management values. There is a high degree of variability in time and across groups of signatories who joined in different years, consistent with the temporal effect observed by Gifford (2010) and the dynamic view of stakeholder relationships (Fassin, 2010; Sachs and Maurer, 2009; Windsor, 2010).

The strong presence of both utilitarian power and pragmatic legitimacy attributes in the responses indicates that an important source of salience for the claim to sign the PRI is the growing recognition of the materiality of ESG and its progressive mainstreaming reflected in demand for SRI (Louche, 2009; Gifford, 2010). This adds to the evidence already existing in the literature that investors see SRI as an avenue to value creation (Crifo and Forget, 2012).

Normative power and organizational legitimacy as sources of salience highlight that signatories consider signing the PRI to be a way of communicating a certain image to clients and other stakeholders, and that the PRI has succeeded in gaining a considerable level of organizational legitimacy over its first five years that investors recognize and want to benefit from by association (Mitchell et al., 1997; Eeasley and Lennox, 2006). The prominence of normative power reinforces other findings such as that private equity funds adopt SRI strategies to differentiate themselves from competitors (Crifo and Forget, 2012).

The dominant presence of normative power provides interesting input for the literature on decoupling, which documents how organizations may decouple policy from practice in an effort to respond to stakeholder pressures (Crilly et al., 2012; Weaver et al., 1999). The dataset available to us gives us limited opportunity to make inferences about the practical implementation of the principles and the closing of the gap between SRI policy and practice (Haack et al., 2012), as we do not track individual organizations over time. However, our analysis does highlight this as an interesting question and hopefully encourages further research in this area. 
Management values are a unique attribute in that they appear to have been of major importance as a source of salience in the first two years in the sample, when the first wave of ethically and ESG- oriented investors signed up to the PRI. But they have been superseded by other factors in the later years when the values motivated signatory recruitment pool was largely exhausted and mainstream investors were drawn to the PRI in large numbers by its growing legitimacy and strong business case (Bromley and Powell, 2012; Haack et al., 2012). Our findings support the proposition that the SRI movement transitions from socially-driven towards profit-oriented (Markowitz et al. 2008). Further research is required to more precisely define and measure the extent to which values play a role in the shift of institutional investment towards ESG integration.

Societal legitimacy found weak evidence in the data. Attributes of coercive power, individual legitimacy, urgency, relative economic size of stakeholder and coalition building find little or no support in signatory survey responses.

This paper contributes to a better understanding of the stakeholder relationship between the PRI and investors. From the analysis we gain an insight into how the sources of salience in this relationship are different from other contexts in which the stakeholder salience model has been applied previously (Gifford, 2010; Siltaoja and Lahdesmaki, 2013; Hautbois, 2012; Parent and Deephouse, 2007; Weber and Marley, 2012). For instance Parent and Deephouse (2007) find power to have the strongest influence on salience, followed by urgency and legitimacy. In the case of PRI signatories, legitimacy was more important than power, and urgency appeared to play no role at all.

This paper also carries out a rare application of stakeholder theory to institutional investors as the organization managing its stakeholders, not as a stakeholder themselves, therefore extending stakeholder theory. It also sheds more light on the sources of salience of private regulatory initiatives in general, and of stakeholder claims as the primary unit of analysis.

The findings have practical implications for both institutions operating in the responsible investment space and investors themselves. A key take away for investors is that the gap between the perception of responsible investment as a legitimate investment strategy by clients and by investors practicing it for sustainable value creation is closing, as illustrated by the simultaneous rise in both utilitarian and normative power. This should encourage and reassure existing and potential responsible investors of the growing legitimacy of this investment approach. Institutions with similar objectives and stakeholder relationships to the PRI can better understand how the sources of stakeholder salience shift over time and transition towards a more business case, normative and legitimacy-driven character. 
This study opens up several avenues for further research. The temporal dimension of stakeholder relationships which is supported by our findings raises many questions around the possible determinants and regularities that may be found in this dynamic. There is also ample opportunity for further research insight into the importance of particular attributes in the salience of private regulatory processes to particular stakeholders. We touch upon this topic by distinguishing between SRI and mainstream investors and public and private pension funds but there remains much more complexity to explore.

Furthermore, the phenomena of conferring legitimacy (Long and Driscoll, 2008; Perez-Batres et al., 2012) and decoupling of policy and practice (Boxenbaum \& Jonsson, 2008; Bromley and Powell, 2012) that we highlighted in association with normative power may provide motivation for further studies in this area, as the concern regarding the true effectiveness of private regulatory processes in changing institutional behavior is widely shared among both practitioners and academics.

The attributes that find no support in our data also raise further questions. One notable absence from the results is individual legitimacy, despite there being qualitative evidence that individuals do play a role in promoting ESG in an institutional setting (Lewis and Juravle, 2009; Waddock, 2010). Urgency was also not mentioned by signatories, continuing a trend of mixed results in the literature (Hautbois, 2012; Parent and Deephouse, 2007; Neville et al., 2011; Weber and Marley, 2010). The question of whether or not these attributes contribute to the salience of private regulatory processes invites further investigation from future research. 


\section{References}

Agle, B. R., Mitchell, R.K. and Sonnenfeld, J.A. (1999). Who Matters to CEOs? An Investigation of Stakeholder Attributes and Salience. Corporate Performance and CEO Values. Academy of Management Journal, 42 (5), 507-525.

Arjalies, D. (2010). A Social Movement Perspective on Finance: How Socially Responsible Investment Mattered. Journal of Business Ethics, 92, 57-78.

Barnett, M.L. (2007). Stakeholder Influence Capacity and the Variability of Financial Returns to Corporate Social Responsibility. The Academy of Management Review, 32(3), 794-816.

Baron, D.P. (2009). A Positive Theory of Moral Management, Social Pressure, and Corporate Social Performance. Journal of Economics \& Management Strategy, 18(1), 7-43.

Bartley, T. (2007). Institutional emergence in an era of globalization: The rise of trans-national private regulation of labor and environmental conditions. American Journal of Sociology, 113(2), 297-351.

Beck, A.C., Campbell, D. and Shrives, P.J. (2010). Content analysis in environmental reporting research: Enrichment and rehearsal of the method in a British-German context. British Accounting Review, 42(3), 207-222.

Bergh, D.D. (1993). Watch the time carefully: The use and misuse of time effects in management research. Journal of Management, 19(1), 683-705.

Blackburn, R. (2006). The global pension crisis: From gray capitalism to responsible accumulation. Politics \& Society, 34(2), 135-186.

Bligh, M.C., Kohles, J.C. and Meindl, J.R. (2004a). Charisma under crisis: Presidential leadership, rhetoric, and media responses before and after the September 11 th terrorist attacks. The Leadership Quarterly, 15(2), 211-239.

Bligh, M. C., Kohles, J. C., and Meindl, J. R. (2004b). Charting the Language of Leadership: A Methodological Investigation of President Bush and the Crisis of 9/11. Journal of Applied Psychology, 89(3), 562-574.

Boritz, J. E., Hayes, L. and Lim, J.H. (2012). What Do Auditor's Reports on Internal Control Tell Us about It Control Weaknesses in Financial Reporting Systems? In CAAA Annual Conference 2012, Charlottetown.

Boxenbaum, E. and Jonsson, S. (2008). Isomorphism, diffusion, and decoupling. In Greenwood, R., Oliver, C., Suddaby, R., Sahlin, K. (eds.), The SAGE Handbook of Organizational Institutionalism. SAGE Publications. 
Bravo, R., J. Matute, and J. M. Pina (2012). Corporate Social Responsibility as a Vehicle to Reveal the Corporate Identity: A Study Focused on the Websites of Spanish Financial Entities. Journal of Business Ethics, 107(2), 129-46.

Brickson, S. L. (2007). Organizational Identity Orientation: The Genesis of the Role of the Firm and Distinct Forms of Social Value. The Academy of Management Review, 32(3), 864-888.

Bromley P., and Powell, W.W. (2012). From Smoke and Mirrors to Walking the Talk: Decoupling in the Contemporary World.' The Academy of Management Annals, 6(1), 483-530.

Brower, J. and Mahajan, V.(2013). Driven to Be Good: A Stakeholder Theory Perspective on the Drivers of Corporate Social Performance. Journal of Business Ethics, 117(2), 313-331.

Burnett, R., Kolbe, H. and Melissa, S. (1991). Content-Analysis Research: An Examination of Applications with Directives for Improving research Reliability and Objectivity. Journal of Consumer Research 18(2), 243-50.

Butterfield, K.D., Trevino, L.K. and Ball, G.A. (1996). Punishment from the Manager's Perspective: A Grounded Investigation and Inductive Model. Academy of Management Journal, 39(6), 14791512.

Campbell, J.L. (2007). Why Would Corporations Behave in Socially Responsible Ways? An Institutional Theory of Corporate Social Responsibility. Academy of Management Review, 32(3), 946-967.

Chang, K., Kim, I. and Li Y. (2014). The Heterogeneous Impact of Corporate Social Responsibility Activities That Target Different Stakeholders. Journal of Business Ethics, 125(2), 211-234.

Chen, J.C. and Roberts, R.W. (2010). Toward a More Coherent Understanding of the Organization-Society Relationship: A Theoretical Consideration for Social and Environmental Accounting Research. Journal of Business Ethics, 97(4), 651-665.

Clarkson, M. (1994). A risk based model of stakeholder theory. Proceedings of the Second Toronto Conference on Stakeholder Theory: Centre for Corporate Social Performance and Ethics, University of Toronto, Toronto, April 1994.

Clarkson, M. (1995). A stakeholder framework for analyzing and evaluating corporate social performance. Academy of Management Review, 20(1), 92-117.

Crane, A. and Ruebottom, T. (2011). Stakeholder Theory and Social Identity: Rethinking Stakeholder Identification. Journal of Business Ethics, 102(1), 77-97.

Crifo, P. and Forget, V.D. (2013). Think Global, Invest Responsible: Why the Private Equity Industry Goes Green. Journal of Business Ethics, 116(1), 21-48. 
Crilly, D., Zollo, M. and Hansen, M.T. (2012). Faking It or Muddling Through? Understanding Decoupling in Response to Stakeholder Pressures. Academy of Management Journal, 55(6), 1429-1448.

Davy, J. A., R. E. White, N. J. Merritt, and K. Gritzmacher (1992). A Derivation of the Underlying Constructs of Just-in-Time Management Systems. Academy of Management Journal, 35(3), 653-70.

Deffner, G. (1985). Microcomputers as Aids in Gottschalk-Gleser Rating. Psychiatry Research, 18 (1985): 151-59.

DiMaggio, P.J. and Powell, W. (1983). The iron case revisited: institutional isomorphism and collective rationality in organizational fields. American Sociological Review, 48(2), 147-160.

Donaldson, T., \& Preston, L. E. (1995). The stakeholder theory of the corporation: Concepts, evidence, and implications. Academy of Management Review, 20(1), 65-91.

Dorado, S. (2005). Institutional Entrepreneurship, Partaking and Convening. Organization studies, 26(3), 385-414.

Dumas, C. and Louche, C. (2011). Mimetic processes in Responsible Investment Mainstreaming. Proceedings of the International Association for Business and Society, 22, 234-245.

Eccles, N.S. (2010). UN Principles for Responsible Investment Signatories and the Anti-Apartheid SRI Movement: A Thought Experiment. Journal of Business Ethics, 95, 415-424.

Edelman, L. (1992). Legal ambiguity and symbolic structures: Organizational mediation of civil rights law. American Journal of Sociology, 97(6), 1531-1576.

Eesley, C. And Lenox, M. J. (2006). Firm Responses to Secondary Stakeholder Action. Strategic Management Journal, 27, 765-781.

Etzioni, A. (1964). Modern Organizations. Englewood Cliffs, NJ: Prentice-Hall.

Fassin, Y. (2010). A Dynamic Perspective in Freeman's Stakeholder Model. Journal of Business Ethics, 96(1), 39-49.

Fisher, I. E., Garnsey, M.R, Goel S. and Tam, K. (2010). The role of text analytics and information retrieval in the accounting domain. Journal of Emerging Technologies in Accounting (7): 1-24.

Freeman, R. Edward (1984). Strategic Management: A stakeholder approach. Boston: Pitman.

Friedman, A.L. \& Miles, S. (2002). Developing Stakeholder Theory. Journal of Management Studies, $39(1), 1-21$.

Frooman, J. (1999). Stakeholders influence strategies. Academy of Management Review, 4(2), 191 205. 
Gifford, J.E. (2010). Effective Shareholder Engagement: Factors that contribute to shareholder salience. Journal of Business Ethics, 92(1), 79-97.

Goodpaster, K. (1991). Business ethics and stakeholder analysis. Business Ethics Quarterly, 1(1), 53-73.

Gottschalk L.A., Gleser G.C. (1969). The measurement of psychological states through the content analysis of verbal behavior. University of California Press, Berkeley.

Gray, R.H., Kouchy, R. and Leavers, S. (1995) Constructing a Research Database of Social and Environmental Reporting by UK Companies: A Methodological Note. Accounting, Auditing and Accountability Journal, 8(2), 44-77.

Greenwood, R., and Hinings, C. R. (1996) Understanding radical organizational change: Bringing together the old and the new institutionalism. Academy of Management Review, 21(4), 10221054.

Greenwood, R., Raynard, M., Kodeih, F., Micelotta, E. R. and Lounsbury, M. (2011). Institutional complexity and organizational responses. Academy of Management Annals, 5(1), 317-71.

Guay, T., Doh, J., Sinclair, G. (2004). Non-Governmental Organizations, Shareholder Activism, and Socially Responsible Investments: Ethical, Strategic, and Governance Implications. Journal of Business Ethics, 52(1), 25-139.

Guyatt, D.J. (2006). Identifying and overcoming behavioral impediments to long term responsible investment: A focus on UK institutional investors, Doctoral dissertation, University of Bath.

Haack, P., Schoeneborn, D. and Wickert, C. (2012). Talking the Talk, Moral Entrapment, Creeping Commitment? Exploring Narrative Dynamics in Corporate Responsibility Standardization. Organization Studies, 33(5-8), 815-845.

Hallett, T. (2010). The myth incarnate: Recoupling processes, turmoil, and inhabited institutions in an urban elementary school. American Sociological Review, 75(1), 52-74.

Hardenbrook, A. (2007). The Equator Principles: The Private Financial Sector's Attempt at Environmental Responsibility. Vanderbilt Journal of Transnational Law, 40(1), 197-232.

Harwood T.G. and Garry, T. (2003). An Overview of Content Analysis. The Marketing Review, 3(4), 479-98.

Harvey, B., and Schaefer, A. (2001). Managing relationships with environmental stakeholders: A study of U. K. water and electricity utilities. Journal of Business Ethics, 30(3), 243-260.

Hautbois, C., Parent, M.M. and Seguin, B. (2012). How to win a bid for major sporting events? A stakeholder analysis of the 2018 Olympic Winter Games French bid. Journal of Business Ethics, 15(3), 263-275. 
Hite, R. E., Bellizzi, J.A. and Fraser, C. (1988) A Content Analysis of Ethical Policy Statements Regarding Marketing Activities. Journal of Business Ethics, 7(10), 771-76.

Holder-Webb, L. Cohen, J.R., Nath, L. and Wood, D. (2009). The supply of corporate social responsibility disclosures among U.s. Firms. Journal of Business Ethics, 84 (4), 497 - 527.

Insch, G.S., Moore, J.E., and Murphy, L.D. (1997). Content Analysis in Leadership Research: Examples, Procedures, and Suggestions for Future Use. Leadership Quarterly, 8(1), 1-25.

Jansson, M. And Biel, A. (2011) Motives to Engage in Sustainable Investment: A Comparison Between Institutional and Private Investors. Sustainable Development, 19(2), 135-142.

Jarvenpaa, B. and Ives, S. L. (1990). Information Technology and Corporate Strategy: A View from the Top. Information Systems Research, 1(4), 351-76.

Jose, A. and Lee, S. (2007). Environmental Reporting of Global Corporations: A Content Analysis based on Website Disclosures. Journal of Business Ethics, 72(4), 307-321.

Juravle, C. and Lewis, A. (2008). Identifying Impediments to SRI in Europe: A Review of the Practitioner and Academic Literature. Business Ethics: A European Review, 17(3), 285-310.

Kaler, J. (2003). Differentiating Stakeholder Theories. Journal of Business Ethics, 46(1), 71-83.

Kaler, J. (2006). Evaluating stakeholder theory. Journal of Business Ethics, 69(3), 249-268.

Knox, S. and Gruar, C. (2007). The Application of Stakeholder Theory to Relationship Marketing Strategy Development in a Non-profit Organization. Journal of Business Ethics, 75(2), 115 135.

Lefebve, M. and Singh, J.B. (1992). The content and focus of Canadian corporate codes of ethics. Journal of Business Ethics, 11(10), 799 - 808.

Lewis, A. and Juravle, C. (2009). Morals, Markets and Sustainable Investments: A Qualitative Study of Champions. Journal of Business Ethics 93(3), 483-494.

Long, B.S. and Driscoll, C. (2008). Codes of ethics and the pursuit of organizational legitimacy: Theoretical and empirical contributions. Journal of Business Ethics 77(2), 4173-189.

Louche, C. (2008). Corporate Social Responsibility: The Investor's Perspective. In S.O. Idowou and W. Filho (eds.), Professionals Perspectives of Corporate Social Responsibility, (pp. 211-231), Springer.

Lounsbury, M. (2007). A tale of two cities: competing logics and practice variation in the professionalizing of mutual funds. Academy of Management Journal, 50(1), 289-307. 
Mackey, A., Mackey, T., and Barney, J. (2007). Corporate Social Responsibility and Firm Performance: Investor Preferences and Corporate Strategies. Academy of Management Review, 32(3): 817-835.

Mainardes, E.W., Alves, H., and Raposo, M. (2012) A model for stakeholder classification and stakeholder relationships. Management Decision, 50(10), 1861-1879.

Mallin, C. A. (2007). Corporate Governance, 2nd Edition (Oxford University Press, Oxford).

Markowitz, L., Louche, C., and Gond, J.P. (2008). How social movements generate new, profitdriven organizational forms: exploring socially responsible investment changes across time and space. Proceedings of the International Association for Business and Society, Vol.18, 246255.

McLachlan, J. and Gardner, J. (2004). A Comparison of Socially Responsible and Conventional Investors. Journal of Business Ethics, 51, 11-25.

Mena, S., and Palazzo, G. (2012). Input and Output Legitimacy of Multi-Stakeholder Initiatives. Business Ethics Quarterly, 22(3), 527-556.

Meyer, R. E., and M. A. Höllerer. (2010) Meaning Structures in a Contested Issue Field: A Topographic Map of Shareholder Value in Austria. Academy of Management Journal, 53(6), 1241-62.

Mitchell, R.K., Agle, B.R. and Wood, D.J. (1997). Toward a theory of stakeholder identification and salience: defining the principle of who and what really counts. Academy of Management Review, 22(4), 853-886.

Molloy, J.C., Chadwick, C., Ployhart, R.E., and Golden, S.J. (2011). Making Intangibles 'Tangible' in Tests of Resource Based Theory: A Multidisciplinary Construct Validation Approach. Journal of Management, 37(5):1496-1518.

Morris, R. (1994). Computerized Content Analysis in Management Research: A Demonstration of Advantages \& Limitations. Journal of Management Information Systems, 20(4), 903-31.

Myllykangas, P. Kujala, J. and Lehtimaki, H. (2010) Legitimacy, and Urgency? Journal of Business Ethics, 96(1), 65-72.

Neville, B., Bell, S.J. and Whitwell, G. (2011). Stakeholder Salience Revisited: Refining, Redefining, and Refueling an Underdeveloped Conceptual Tool. Journal of Business Ethics, 102(1), 357378.

Parent, M. M. and Deephouse, D.L. (2007). A Case Study of Stakeholder Identification and Prioritization by Managers. Journal of Business Ethics, 75(1): 1-23.

Parker, L., (2005). Social and environmental accountability research: A view from the commentary box. Accounting, Auditing and Accountability Journal, 18(6), 842-860. 
Pennebaker, J.W. and Lay, T.C. (2002). Language Use and Personality During Crises: Analyses of Mayor Rudolph Giuliani's Press Conferences. Journal of Research in Personality, 36(1), 271-282.

Perez-Batres, L.A., Doh, J.P., Miller, V.V. and Pisani, M.J. (2012). Stakeholder Pressures as Determinants of CSR Strategic Choice: Why do Firms Choose Symbolic Versus Substantive Self-Regulatory Codes of Conduct? Journal of Business Ethics 110, 157-172.

Power, M. (1997). The audit society. Oxford, UK: Oxford University Press.

Richardson, B.J. (2009). Keeping Ethical Investment Ethical: Regulatory Issues for Investing for Sustainability. Journal of Business Ethics 87(1), 555-572.

Rust, R.T. and Cooil, B. (1994) Reliability Measures for Qualitative Data: Theory and Implications. Journal of Marketing Research 31(1), 1-14.

Rowley, T. (1997). Moving beyond dyadic ties: a network theory of stakeholder influences. Academy of Management Review, 22(4), 887-910.

Sachs, S. and Maurer, M. (2009). Toward Dynamic Corporate Stakeholder Responsibility. Journal of Business Ethics 85(1), 535-544.

Sakuma, K. and Louche C. (2008). Socially Responsible Investment in Japan: Its Mechanism and Drivers. Journal of Business Ethics, 82, 425-448.

Sandberg, J. (2011). Socially Responsible Investment and Fiduciary Duty: Putting the Freshfields Report into Perspective. Journal of Business Ethics, 101(1), 143-162.

Sandberg, J. (2013). (Re-)Interpreting Fiduciary Duty to Justify Socially Responsible Investment for Pension Funds? Corporate Governance - An International Review, 21(5), 436-446.

Saldana, J. (2009). The Coding Manual of Qualitative Researchers. Sage Publications Ltd., London.

Sauder, M., and Espeland, W. (2009). The discipline of rankings: Tight coupling and organizational change. American Sociological Review, 74(1), 63-82.

Scott, W. R. (2008). Institutions and organizations: Ideas and interests, 3rd edition. Thousand Oaks, CA: Sage.

Sethi, S. P. (2005). Investing in socially responsible companies is a must for public pension funds-because there is no better alternative. Journal of Business Ethics, 56(1), 99-12.

Sheth, H. and Babiak, K.M. (2010). Beyond the Game: Perceptions and Practices of Corporate Social Responsibility in the Professional Sport Industry. Journal of Business Ethics, 91(3), 433 450.

Sievanen, R., Hannu, R. and Scholtens, B. (2013). The Drivers of Responsible Investment: The Case of European Pension Funds. Journal of Business Ethics, 117(1), 137-151. 
Siltaoja, M. and Lahdesmaki, M. (2013). From Rationality to Emotionally Embedded Relations: Envy as a Signal of Power in Stakeholder Relations. Journal of Business Ethics, December 2013.

Sobczak, A. and Havard, C. (2015). Stakeholders' Influence on French Unions' CSR Strategies. Journal of Business Ethics, 129(3), 311- 324.

Sparkes, R. (2002). Socially Responsible Investment: A Global Revolution. Wiley, Chichester.

Sparkes, R. and Coweton, C.J. (2004). The Maturing of Socially Responsible Investment: A Review of the Developing Link With Corporate Social Responsibility. Journal of Business Ethics, 52(1), 45-57.

Spindler, G. and L. (1997). Cultural Process and Etnography. Waveland Press Inc.

Strathern, M. (2000). Audit cultures: Anthropological studies in accountability, ethics and the Academy. Routledge, New York.

Stray, S. (2008). Environmental Reporting: the UK water and energy industries: a research note. Journal of Business Ethics, 80(4), 697-710.

Tashman, P. and Raelin, J. (2013). Who and What Really Matters to the Firm: Moving Stakeholder Salience beyond Managerial Perceptions. Business Ethics Quarterly, 23(14), 591-616.

Tilcsik, A. (2010). From ritual to reality: Demography, ideology, and decoupling in a postcommunist government agency. Academy of Management Journal, 53(6), 1474-1498.

Valentine, S. and Fleischman, G. (2008). Ethics Programs, Perceived Corporate Social Responsibility and Job Satisfaction. Journal of Business Ethics, 77(2), 159-172.

Verbeke, A. and Tung, V. (2013). The future of stakeholder management theory: a temporal perspective. Journal of business ethics, 112(3), 529-543.

Waddock, S. (2011). From Individual to Institution: On Making the World Different. Journal of Business Ethics, 94, 9-12.

Weaver, G.R., Trevino, L.K. and Cochran, P.L. (1999). Integrated and Decoupled Corporate Social Performance: Management Commitments, External Pressures, and Corporate Ethics Practices. Academy of Management Journal, 42(5), 539-552.

Weber, J. and Marley, K. (2012). In Search of Stakeholder Salience: Exploring Corporate Social and Sustainability Reports. Business and Society, 51(4), 626-649.

Windsor, D. (2011). The Role of Dynamics in Stakeholder Thinking. Journal of Business Ethics, 96(1), 79-87.

Wolfe R.A., Gephart, R.P. and Johnson, T.E. (1993). Computer-facilitated qualitative data analysis: Potential contributions to management research. Journal of Management, 19(1), 637-660. 
Woods, C. and Urwin, R. (2010). Putting Sustainable Investing into Practice: A Governance Framework for Pension Funds. Journal of Business Ethics, 92(1), 1-19.

FIGURE 1:

Growth of the collective AUM of PRI signatories. Source: http://www.unpri.org Accessed 23/06/2014. Last Updated: 23/06/2014.

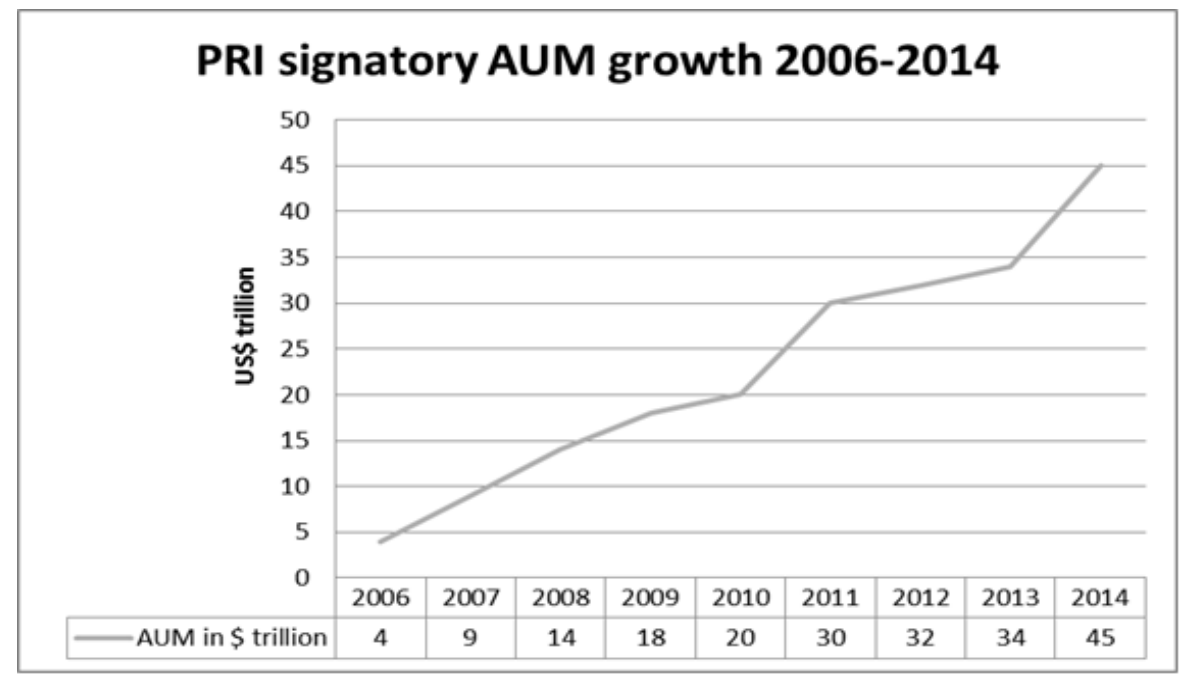

FIGURE 2:

The six Principles for Responsible Investment:

1) We will incorporate ESG issues into investment analysis and decision-making processes.

2) We will be active owners and incorporate ESG issues into our ownership policies and practices.

3) We will seek appropriate disclosure on ESG issues by the entities in which we invest.

4) We will promote acceptance and implementation of the Principles within the investment industry. 
5) We will work together to enhance our effectiveness in implementing the Principles.

6) We will each report on our activities and progress towards implementing the Principles.

\section{TABLE 1:}

This table displays the wording of and number of responses to the survey question analyzed vs. mandatory questions and the proportion of asset owners and asset managers in the respondent group.

\begin{tabular}{|l|l|l|l|l|l|l|}
\hline & $\begin{array}{l}\text { Number } \\
\text { of } \\
\text { responses } \\
\text { to the } \\
\text { question } \\
\text { analyzed }\end{array}$ & $\begin{array}{l}\text { Number of } \\
\text { responses } \\
\text { to the } \\
\text { obligatory } \\
\text { questions }\end{array}$ & $\begin{array}{l}\text { Respondents } \\
\text { to question } \\
\text { analyzed as a } \\
\text { proportion of } \\
\text { all } \\
\text { signatories }\end{array}$ & $\begin{array}{l}\text { Wording of } \\
\text { the question } \\
\text { by survey year }\end{array}$ & $\begin{array}{l}\text { \% of asset } \\
\text { managers } \\
\text { among all } \\
\text { respondents } \\
\text { in survey } \\
\text { year }\end{array}$ & $\begin{array}{l}\text { \% of asset } \\
\text { owners } \\
\text { among all } \\
\text { respondents } \\
\text { in survey } \\
\text { year }\end{array}$ \\
\hline 2007 & 97 & 105 & $63 \%$ & $\begin{array}{l}\text { Why did your } \\
\text { organization } \\
\text { join the PRI? }\end{array}$ & 43 & 57 \\
\hline 2009 & 245 & 286 & $59 \%$ & $\begin{array}{l}\text { Why did your } \\
\text { organization } \\
\text { join the PRI? }\end{array}$ & 46 & 54 \\
\hline 2010 & 375 & 433 & $59 \%$ & $\begin{array}{l}\text { Please } \\
\text { describe the } \\
\text { benefits you } \\
\text { have enjoyed } \\
\text { as a result of } \\
\text { signing the } \\
\text { PRI. }\end{array}$ & 55 & 45 \\
\hline 464 & 540 & $57 \%$ & $\begin{array}{l}\text { Please } \\
\text { describe the } \\
\text { benefits you } \\
\text { have enjoyed } \\
\text { as a result of } \\
\text { signing the } \\
\text { PRI. }\end{array}$ & $\begin{array}{l}\text { Please } \\
\text { describe the } \\
\text { benefits you } \\
\text { have enjoyed }\end{array}$ & 62 & 38 \\
\hline
\end{tabular}

\footnotetext{
${ }^{3}$ as of the month the survey was due in the given year
} 


\begin{tabular}{|l|l|l|l|l|l|}
\hline & & $\begin{array}{l}\text { as a result of } \\
\text { signing the } \\
\text { PRI. }\end{array}$ & & \\
\hline
\end{tabular}


TABLE 2: summarizes the aggregate numbers of responses that supported each attribute from the framework in each survey year.

\begin{tabular}{|c|c|c|c|c|c|c|c|c|c|c|c|c|c|c|c|c|c|c|c|c|c|c|c|}
\hline MITCHELL & PC & PC \% & PU & PU \% & PN & PN\% & $\mathrm{LI}$ & LI\% & LO & LO\% & LS & LS\% & UR & UR\% & GIFFORD & MV & MV\% & PL & PL\% & RES & RES\% & $\mathrm{CB}$ & CB\% \\
\hline 2007 & 0 & $0 \%$ & 1 & $1 \%$ & 4 & $4 \%$ & 0 & $0 \%$ & 2 & $2 \%$ & 4 & $4 \%$ & 0 & $0 \%$ & & 73 & $75 \%$ & 30 & $31 \%$ & 0 & $0 \%$ & 0 & $0 \%$ \\
\hline 2008 & 0 & $0 \%$ & 10 & $6 \%$ & 10 & $6 \%$ & 0 & $0 \%$ & 2 & $1 \%$ & 6 & $4 \%$ & 0 & $0 \%$ & & 120 & $78 \%$ & 46 & $30 \%$ & 0 & $0 \%$ & 0 & $0 \%$ \\
\hline 2009 & 0 & $0 \%$ & 22 & $9 \%$ & 37 & $15 \%$ & 0 & $0 \%$ & 29 & $12 \%$ & 2 & $1 \%$ & 0 & $0 \%$ & & 26 & $11 \%$ & 68 & $28 \%$ & 2 & $1 \%$ & 0 & $0 \%$ \\
\hline 2010 & 1 & $1 \%$ & 52 & $14 \%$ & 69 & $18 \%$ & 0 & $0 \%$ & 70 & $19 \%$ & 6 & $2 \%$ & 0 & $0 \%$ & & 45 & $12 \%$ & 19 & $53 \%$ & 6 & $2 \%$ & 0 & \\
\hline 2011 & 0 & $0 \%$ & 68 & $15 \%$ & 98 & $21 \%$ & 0 & $0 \%$ & 70 & $15 \%$ & 10 & $2 \%$ & 0 & $0 \%$ & & 52 & $11 \%$ & 24 & $52 \%$ & 7 & $1 \%$ & 0 & \\
\hline
\end{tabular}

$\begin{array}{llllll}\text { PC } & \text { Power coercive } & \text { LI } & \text { Legitimacy individual } & \text { MV } & \text { Management values } \\ \text { PU } & \text { Power utilitarian } & \text { LO } & \text { Legitimacy organizational } & \text { PL } & \text { Pragmatic legitimacy } \\ \text { PN } & \text { Power normative } & \text { LS } & \text { Legitimacy societal } & \text { RES } & \text { Relative economic size of stakeholder } \\ & & \text { UR } & \text { urgency } & \text { CB } & \text { Coalition building }\end{array}$

TABLE 3: shows the difference between asset owner ( $\mathrm{AO}$ ) and investment manager (IM) answers for some key attributes.

\begin{tabular}{|c|c|c|c|c|c|c|c|c|c|c|c|c|c|}
\hline Mitchel et al. & MV IM & MV AO & PL IM & PL AO & PU IM & PU AO & PN IM & PN AO & Gifford & MV IM & MV AO & PL IM & PL AO \\
\hline 2007 & 0.90 & 0.60 & 0.29 & 0.31 & 0.048 & 0.00 & 0.00 & 0.07 & & 0.90 & 0.60 & 0.29 & 0.31 \\
\hline 2008 & 0.71 & 0.58 & 0.25 & 0.25 & 0.086 & 0.02 & 0.02 & 0.08 & & 0.71 & 0.58 & 0.25 & 0.25 \\
\hline 2009 & 0.08 & 0.07 & 0.19 & 0.21 & 0.11 & 0.03 & 0.12 & 0.16 & & 0.08 & 0.07 & 0.19 & 0.21 \\
\hline 2010 & 0.11 & 0.06 & 0.44 & 0.31 & 0.16 & 0.05 & 0.18 & 0.14 & & 0.11 & 0.06 & 0.44 & 0.31 \\
\hline 2011 & 0.07 & 0.05 & 0.44 & 0.27 & 0.14 & 0.12 & 0.18 & 0.20 & & 0.07 & 0.05 & 0.44 & 0.27 \\
\hline
\end{tabular}


TABLE 4: contains the itemized total number of responses supporting the most relevant attributes by signature year of respondent. The column names are the signature years. The left column contains absolute numbers and the right percentages.

\begin{tabular}{|c|c|c|c|c|c|c|c|c|c|c|c|}
\hline \multirow[t]{6}{*}{ Utilitarian power } & & 2006 & 2007 & 2008 & 2009 & 2010 & 2006 & 2007 & 2008 & 2009 & 2010 \\
\hline & 2007 & 1 & 0 & & & & $1 \%$ & $0 \%$ & $0 \%$ & $0 \%$ & $0 \%$ \\
\hline & 2008 & 6 & 3 & 1 & & & $4 \%$ & $2 \%$ & $1 \%$ & $0 \%$ & $0 \%$ \\
\hline & 2009 & 4 & 11 & 6 & 1 & & $2 \%$ & $4 \%$ & $2 \%$ & $0 \%$ & $0 \%$ \\
\hline & 2010 & 6 & 13 & 15 & 17 & 1 & $2 \%$ & $3 \%$ & $4 \%$ & $5 \%$ & $0 \%$ \\
\hline & 2011 & 7 & 9 & 14 & 21 & 17 & $2 \%$ & $2 \%$ & $3 \%$ & $5 \%$ & $4 \%$ \\
\hline \multirow[t]{6}{*}{ Normative power } & 2007 & 2 & 2 & & & & & & & & \\
\hline & 2008 & 6 & 4 & 0 & & & $2 \%$ & $2 \%$ & $0 \%$ & $0 \%$ & $0 \%$ \\
\hline & 2009 & 10 & 19 & 7 & 1 & & $4 \%$ & $3 \%$ & $0 \%$ & $0 \%$ & $0 \%$ \\
\hline & 2010 & 12 & 20 & 25 & 12 & 0 & $4 \%$ & $8 \%$ & $3 \%$ & $0 \%$ & $0 \%$ \\
\hline & 2011 & 18 & 17 & 20 & 31 & 12 & $3 \%$ & $5 \%$ & $7 \%$ & $3 \%$ & $0 \%$ \\
\hline & & & & & & & $4 \%$ & $4 \%$ & $4 \%$ & $7 \%$ & $3 \%$ \\
\hline \multicolumn{12}{|c|}{ Management values } \\
\hline & 2007 & 43 & 30 & & & & $44 \%$ & $31 \%$ & $0 \%$ & $0 \%$ & $0 \%$ \\
\hline & 2008 & 69 & 41 & 10 & & & $45 \%$ & $27 \%$ & $6 \%$ & $0 \%$ & $0 \%$ \\
\hline & 2009 & 15 & 11 & 0 & 0 & & $\begin{array}{r}4 J \% \\
6 \%\end{array}$ & $\begin{array}{r}210 \\
4 \%\end{array}$ & $0 \%$ & $0 \%$ & $\begin{array}{l}0 \% \\
0 \%\end{array}$ \\
\hline & 2010 & 17 & 18 & 10 & 0 & 0 & $\begin{array}{l}0 \% \\
5 \%\end{array}$ & $\begin{array}{l}4 \% \\
5 \%\end{array}$ & $\begin{array}{l}0 \% \\
3 \%\end{array}$ & $0 \%$ & $0 \%$ \\
\hline & 2011 & 15 & 18 & 18 & 1 & 0 & $5 \%$ & $5 \%$ & $3 \%$ & $0 \%$ & $0 \%$ \\
\hline \multicolumn{7}{|c|}{ Pragmatic legitimacy } & $3 \%$ & $4 \%$ & $4 \%$ & $0 \%$ & $0 \%$ \\
\hline & 2007 & 20 & 10 & & & & & & & & \\
\hline & 2008 & 26 & 17 & 3 & & & $21 \%$ & $10 \%$ & $0 \%$ & $0 \%$ & $0 \%$ \\
\hline & 2009 & 33 & 35 & 0 & 0 & & $17 \%$ & $11 \%$ & $2 \%$ & $0 \%$ & $0 \%$ \\
\hline & 2010 & 52 & 51 & 60 & 35 & 0 & $13 \%$ & $14 \%$ & $0 \%$ & $0 \%$ & $0 \%$ \\
\hline & 2011 & 54 & 48 & 65 & 54 & 22 & $14 \%$ & $14 \%$ & $16 \%$ & $9 \%$ & $0 \%$ \\
\hline \multirow[t]{7}{*}{ Societal legitimacy } & & 2006 & 2007 & 2008 & 2009 & 2010 & $12 \%$ & $10 \%$ & $14 \%$ & $12 \%$ & $5 \%$ \\
\hline & 2007 & 2 & 2 & & & & & & & & \\
\hline & 2008 & 5 & 1 & 0 & & & $2 \%$ & $2 \%$ & $0 \%$ & $0 \%$ & $0 \%$ \\
\hline & 2009 & 0 & 1 & 0 & 1 & & $3 \%$ & $1 \%$ & $0 \%$ & $0 \%$ & $0 \%$ \\
\hline & 2010 & 2 & 1 & 3 & 0 & 0 & $0 \%$ & $0 \%$ & $0 \%$ & $0 \%$ & $0 \%$ \\
\hline & 2011 & 3 & 1 & 2 & 3 & 1 & $1 \%$ & $0 \%$ & $1 \%$ & $0 \%$ & $0 \%$ \\
\hline & & & & & & & $1 \%$ & $0 \%$ & $0 \%$ & $1 \%$ & $0 \%$ \\
\hline \multicolumn{2}{|c|}{ Organizational legitimacy } & 2006 & 2007 & 2008 & 2009 & 2010 & & & & & \\
\hline & 2007 & 2 & 0 & & & & $2 \%$ & $0 \%$ & $0 \%$ & $0 \%$ & $0 \%$ \\
\hline & 2008 & 2 & 0 & 0 & & & $1 \%$ & $0 \%$ & $0 \%$ & $0 \%$ & $0 \%$ \\
\hline & 2009 & 12 & 17 & 0 & 0 & & $5 \%$ & $7 \%$ & $0 \%$ & $0 \%$ & $0 \%$ \\
\hline & 2010 & 24 & 23 & 19 & 4 & 0 & $6 \%$ & $6 \%$ & $5 \%$ & $1 \%$ & $0 \%$ \\
\hline & 2011 & 23 & 20 & 18 & 5 & 4 & & & & & \\
\hline
\end{tabular}


$\begin{array}{llll}4 \% & 4 \% & 1 \% & 1 \%\end{array}$ 
FIGURE 3: Proportion of respondents whose responses indicated management values and pragmatic legitimacy as sources of salience in the process of signing the PRI, split into asset managers and investment managers.

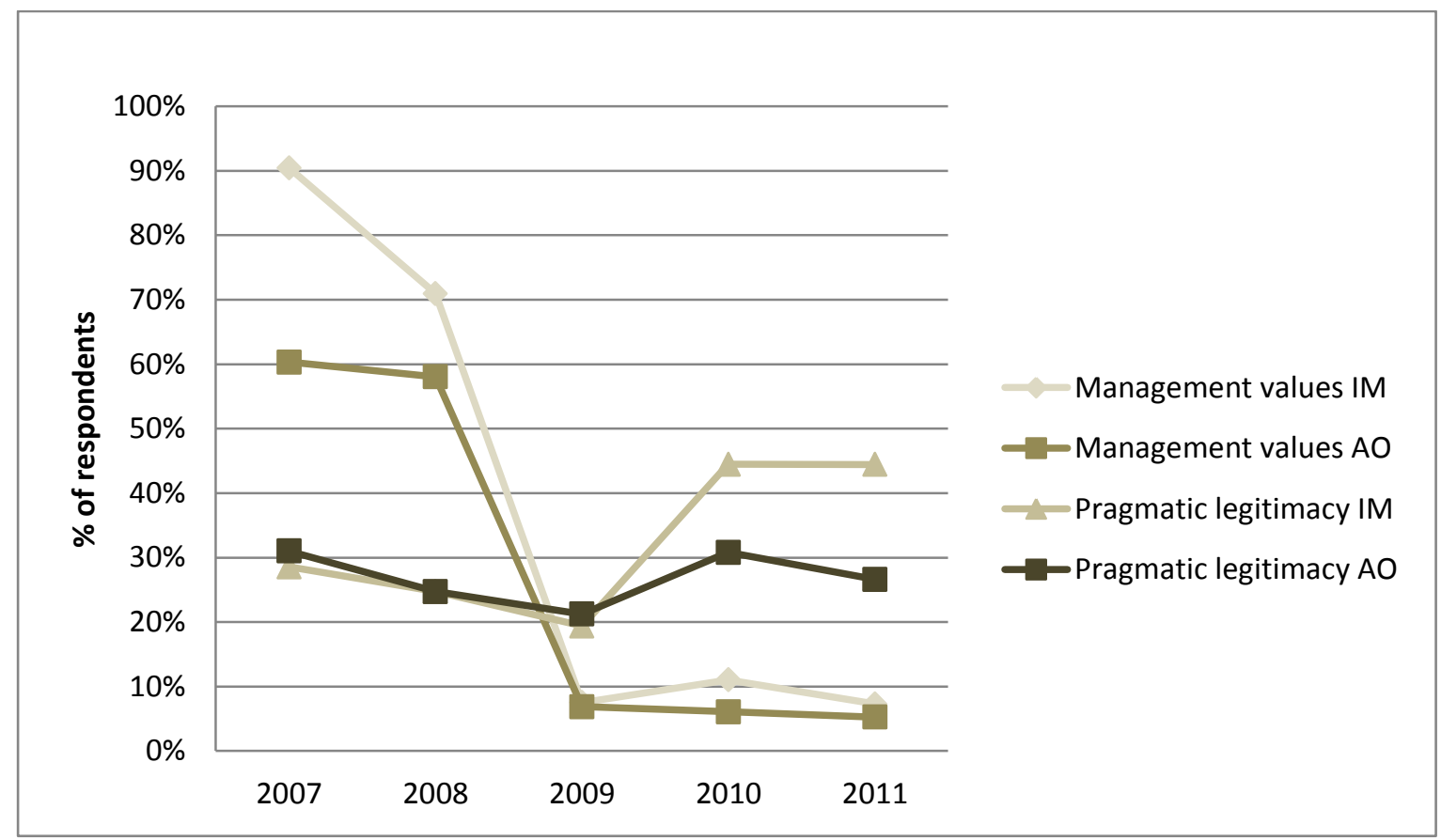

FIGURE 4: Number of respondents by signature year whose responses supported the attribute of management values.

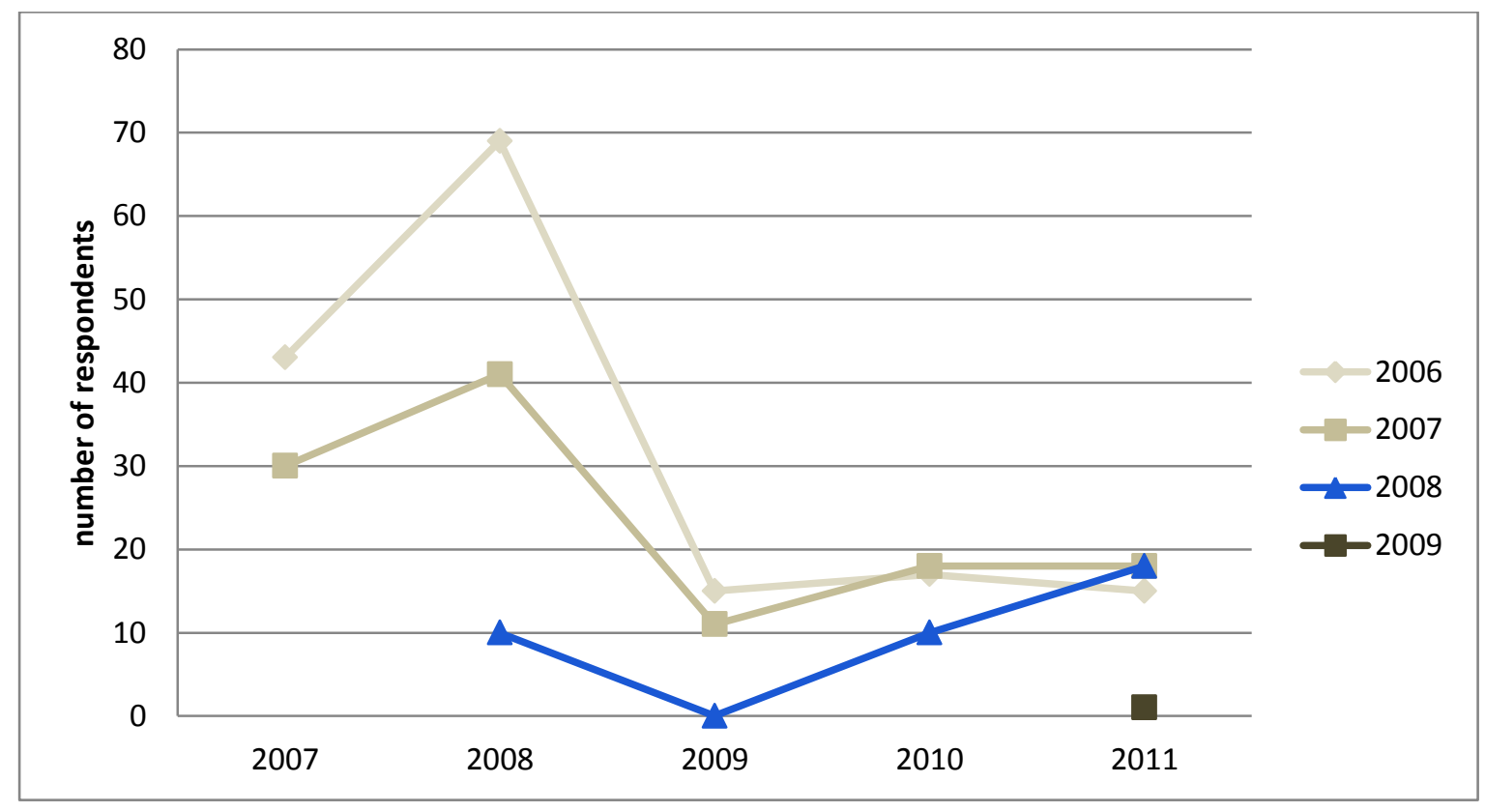


